\title{
Analysis of the Registers in Sport Articles in the Jakarta Post Online Newspaper
}

\author{
Rizki Aziza \\ Post-Graduate Students of English Education, University of Lampung, Indonesia \\ 凶 email: rizkiaziza97@gmail.com
}

\begin{abstract}
Received:
01 December 2021

Revised:

02 December

2021

Accepted:

02 January 2022

Published:

02 January 2022

ABSTRACT

This research aimed to examine sport registers in online newspaper, and to obtain a list of words and phrases that are commonly used by the sport team when mentioning certain terms in the field of sport. The study was constrained by an examination of sport registers in the Jakarta Post online newspaper. The analytical research method and document analysis were used in this study. The study's findings were as follows: In the first article, it was found that six (6) or $31.5 \%$ data were classified as borrowing words, one (1) or $5.2 \%$ were acronyms, two (2) or $10.6 \%$ were abbreviations, two (2) or $10.6 \%$ were compounding, and eight (8) or $42.1 \%$ were categorized as inflections. In the second article, it was found that twelve (12) or 52,2\% data were classified as borrowing words, one (1) or $4,3 \%$ were abbreviations, two (2) or $8,7 \%$ were compounding, and eight (8) or $34,8 \%$ were categorized as inflections. Moreover, in the third article, it was found that seven (7) or 31,8\% data were classified as borrowing words, four (4) or $18,2 \%$ as acronyms, two (2) or $9,1 \%$ were abbreviations, one (1) or 4,5\% were compounding, and eight (8) or $36,4 \%$ were categorized as inflections. There are not only words but phrase registers were found sport articles. There are 11 phrases found in three online news of sport article. It can be concluded that there are many registers to be found in sports news in the Jakarta Post online newspaper.
\end{abstract}

Keywords: Sport Registers, Online Newspaper, Word Formation.

\section{INTRODUCTION}

According to Holmes (2014), language and society are interested in explaining why we speak differently in different social contexts, and it is concerned with identifying the social functions of language and the ways it is used to convey social meaning. Sociolinguistics is also the study of language variation in the real world. There are several definitions of language variation. Hudson in Wardaugh (1998) defines a variety of language as a collection of linguistic items with a similar distribution. Alwasilah (1985) implies that there are six types of language variation, namely Style, Slang, Colloquial, Jargon, Argot, and Register. In this research, the researcher focused on Register.

Holmes (2001) states that register in sociolinguistics is described as the language used by groups of people with common interest or jobs, or the language 
which is used in a situational associated with such community. Registers are a type of different language used in sociolinguistics. It means that register is the language used by speakers in their natural daily activities. Furthermore, Holmes (2013) explains that the linguistic features of a register are variations that provide speakers with a choice of ways of expressing themselves that include specific lexicon choices, syntactical patterns, word structures (morphology), and pronunciation. Thus, linguistic features such as vocabulary, sentence structure, morphology, and pronunciation or phonetics can be deduced (Ambarsari \& Rusnaningtias, 2016). According to Pateda (1987) the function of register are casual, deliberate, consultative, oratorical, and intimate.

We frequently see and read English terms in mass media, such as newspapers and magazines. There are registers for politics, economics, social issues, laws, health, and sports. Several strange registers, particularly English registers, frequently cause a problem for readers who do not understand the meaning of those registers. The reader must be able to translate and catch the meaning in order to know and understand the strange registers in mass media. Readers who understand the meaning of the registers will enjoy and be satisfied with what they read. However, it will be difficult for those who do not understand the register meaning to understand the content of the news, resulting in an unsatisfied reader. Considering to the register used in a certain group or community, there is also registers used in sport news and articles, many athletes, for example, use their vocabulary and prior knowledge of sport in communication that other people cannot understand. They use it to help them communicate and simplify their speaking.

Sport is also more popular among men than among women. As a result, women's prior knowledge is limited, and there are only a few women who enjoy sports. While studying linguistics, students frequently studied about registers, particularly those related to English sport registers, which piqued the writer's interest in conducting this research on English sport registers in mass media.

Nowadays most of people prefer to seek information through online news circulating on the internet. In this case, the researcher uses The Jakarta Post as online media which serves broad information accurately. According to its website on www.thejakarta.com, the Jakarta Post is daily English language newspaper in Indonesia which is owned by PT Bina Media Tenggara with the head office located in the nation capital, Jakarta. This research has compared and found some similarity and difference to the research that has been done by several research.

The first previous study is conducted by Rosaria (2008). From her research, she concluded that English register used in trading in "Bisnis Indonesia" newspaper based on the change of meaning the real meaning and the new meaning of English register used in trading "Bisnis Indonesia" newspaper that do not have the real meaning as the highest percentage than another.

The second previous study is conducted by Mega (2012) which gives some information about the linguistics form and the meaning of English register, the 
conclusion of the study shows that: 1) the linguistic forms of the register are words and phrases. The words consist of 2 categories; there are single word and compound word. This research found 8 noun phrases, 4 verb phrases, 3 adjective phrases, and 7 compound words. 2) There no phrases found in this research.

The last previous study is conducted by Nafia and Rustono (2019), the result of this study was (1) based on lingual units are, registers in the form of base words, words with affixes, compound words, and phrases, (2) based on the origin of the language are, register in Indonesian language, Javanese loanwords, Arabic loanwords, and Sundanese loanwords, (3) based on the register types, it is divided into open registers and closed registers.

Therefore, this study aims to analyze registers about sport in online written news. The objectives of this present study are to find out list of words and phrases commonly used by the team in mentioning certain terms in sports articles; the most common type of word formation found on the sports list in the Jakarta Post online newspaper; and the contribution of research findings for the general public as news readers.

The term "register" was first utilized by Thomas B. Reid in 1956 in his article "Linguistic, structuralism and philology" (Moreno \& Skorczynska, 2013). Register is form which defines as the variation of language in any given context according to the use. It supported by Southerland and Katamba in Budiarsa (2015) that the use the language is as a communication for certain purpose. In addition, Halliday (1978) stated that register can be defined as the configuration of semantic resources that the member of a culture typically associates with a situation. In line, Holmes (2001) register is the specific vocabulary associated with different occupational groups. According to Wardaugh (1992) register is the way used by a speaker in using language differently in different circumstances. Furthermore, Trudgill in Mulyani and Suryani (2019) register refers to how an individual performs in particular contexts or social settings, the language style or register that people use varies according to purpose, situation and relationship.

It can be taken conclusion that register is words or phrases used by group of people who have the same interest or job, then they have and use certain terms. They might be same on its phonology and morphology form but have different meaning based on its field and context.

Word formation process is a process which form and create a new words with certain processes (Bauer, 1983). Plag (2003) divides word formation process into four kinds such as compounding, abbreviation, blending, and affixation. Delahunty and Garvey (2010), on the other hand, propose that word formation process includes coinage, conversion, acronym, borrowing. Furthermore, Bauer (1983) describes word formation as a traditional label, and one which is useful, but it does not generally cover all possible ways of forming everything that can be called a word. He focused on nine kinds of word formation they are coinage words, borrowing, blending, clipping, acronym, abbreviation, compounding, back formation, and inflection. The explanation of each term is as follows: 


\section{Coinage}

Yule (2006) states that coinage word is the invention of totally new terms. Coinage process is defined as the way of creating new word with referring to the most topical sources which are invented to the trade name for the certain commercial products and it becomes the general terms used in society.

It can be concluded that is the creation or invention of totally new terms, without employing any other words already in existence. For the example such as Honda for motorcycle, Vaseline for hand and body lotion. Besides, the addition to new words based on the name of person or a place. For example: Fahrenheit (from the German, Gabriel Fahrenheit), Volt (from the Italian, Alessandro Volta) etc.

\section{Borrowing}

According to Delahunty and Garvey (2010), borrowing is the process of word formation by borrowing or taking vocabulary of other languages. Moreover, Yule (2006) assumes borrowing is the process of taking over words from other languages. It can be concluded that borrowing is actually borrowing words from foreign languages. The English language has been borrowing words from "nearly a hundred languages in the last hundred years" and today, French loan words are especially popular.

\section{Blending}

Katamba (1993) said that blending is the combination of two separate forms to produce a single new term. It means to combine the parts of two words to produce a new word. The first part of the first word is blended with the last part of the second word. The examples are breakfast and lunch become brunch, education and entertainment become edutainment, etc.

\section{Clipping}

Katamba (1993) states that clipping is a process of new words by shortening the polysyllabic word or by deleting one or more syllables. It can be concluded that is to cut or to shorten the longer word, such as in advertisement becomes ads, information becomes info, and laboratory becomes lab, etc.

\section{Acronym}

According to Yule (2006) acronym is word formed from the initial letters of a name or combining initial letters of a series of words. It means, the acronym comes from the preliminary sound (letter or letters) of the phrases or of a word and its miles mentioned as a word. We can find acronyms in FIFA, FIFPRO, etc.

\section{Abbreviation}

An abbreviation is formed by taking the initial letters which does not result in well-formed syllables as stated Bauer (1983). Furthermore, Delahunty and Garvey (2010), abbreviation is the process of word formation by dropping part of the word itself. It can be inferred that abbreviation is the process of reducing certain word and 
using its first letter as the initials. An abbreviation is a shortened form of a word or phrase, such as PRSI (Persatuan Renang Seluruh Indonesia) etc.

\section{Compounding}

According to Yule (2006) compound words are formed by combining two or more words into one unit with a perceptible lexical meaning. The two words can be the combination of noun+noun, adjective+noun, noun+verb, noun+adverb, verb+adverb, verb+preposition, and preposition+preposition. Compounding process results on compound words such as football (foot+ball), breaststroke (breast+stroke) etc. It can be concluded that when we combine two or more words to produce a single word with new meaning, it means we apply compounding.

\section{Back-formation}

Yule (2006) states back formation is a very specialized type of reduction process. Furthermore, O'Grady and Guzman in Faradisa, Aziz and Yasin (2019) affirm that backformation is a process creates a new word by removing a real or supposed affix from another word in the language. In simple definition back-formation is the process of word formation which creates new word by changing the word class. Typically, a word of one type usually noun is reduced to form a word of another type usually a verb. i.e television to televise, emotion to emote, donation to donate, etc.

\section{Inflection}

Lyons in Bauer (1983) defines inflection produces from the stem (or stems) of a given lexeme all the word-forms of that lexeme which occur in syntactically determined environment. There are some types of inflection: plural (more than one), word as sign to change third person singular, past time (past tense), state time that goes on now (present participle/ present continuous tense), and degree of comparison. It can be concluded that inflection is viewed as the process of adding very general meanings to existing words, not as the creation of new words, such as player=players, swim $=$ swimming, etc.

\section{METHOD}

This type of study was descriptive qualitative research. According to Cresswell, (1992) states that a qualitative research is a research collect data themselves through document. Sugiyono (2008) stated that in qualitative research, the instrument is the researcher themselves. Hence, the researcher should be validated by themselves about their ability in conducting research.

Descriptive research studies are designed to obtain information concerning the current status of phenomenon (see Apriyanto \& Anum, 2018; Ayu et al., 2020; Dalman et al., 2020; Kusuma \& Apriyanto, 2018; Subyantoro \& Apriyanto, 2020). It can be seen from the data which are collected. It contains words and sentences rather than number. The researcher takes qualitative research because this research is to 
identify the register word and definitions \& functions register used in sport articles in The Jakarta Post Online Newspaper.

This study's data consists of three sport articles published in the Jakarta Post online newspaper between July-September 2021. The subject of this study is sport register found in Jakarta Post online newspaper. The data was obtained from www.thejakartapost.com, entitled "Indonesian swimming sensation Elysha Pribadi breaks three national records in Australia", "England ready to make history in Euro final as Italy aim to spoil party" and "Most fans back more frequent World Cups: FIFA".

The writer's material gathering tool in this study was document analysis. Document analysis is used to collect data from archives and documents both inside and outside the organization that have something to do with the research. According to Bowen (2009), document analysis is a type of qualitative research in which documents are interpreted by the researcher to give voice and meaning to an assessment topic. Document analysis includes coding content into themes, similar to how focus group or interview transcripts are analyzed.

The writer took the following steps in gathering data and conducting analysis:

1. Reading carefully several sports articles in the Jakarta Post Sport column.

2. Searching and categorizing data from sport registers that can be classified.

3. Grouping each data into a table from the three articles of Jakarta Online Post Newspaper.

4. Analyzing the data by determining the word formation of the words and phrases discovered.

5. Drawing the conclusions and suggestions based on the data analysis.

6. Constructing the output of the study.

\section{FINDINGS AND DISCUSSION}

\section{Findings}

Based on the linguistic form, the writer has distinguished two kinds of data, namely words and phrases. Researcher distinguished the research results into four tables. The total number of register words is 64 word registers which are classified into 5 types of word formation, and 11 register phrases. The results of the researcher's analysis were 19 registers in the first article, 23 registers in the second article, and 22 registers in the third article. So it has been found the most register data in the second article. From the three articles that have been analyzed, the writer has found 25 borrowing words, 5 acronyms, 5 abbreviations, 5 compounding, and 24 inflection words. The registers have been detailed in the table 1.

Table 1. Registers Found in the First Sport Article of Jakarta Post Online Newspaper

\begin{tabular}{|c|c|c|c|c|}
\hline No & Word Formation & Registers & Frequency & Percentage \\
\hline 1. & Coinage & & - & - \\
\hline 2. & Borrowing & $\begin{array}{l}\text { National, Silver, Challenge, Olympic, } \\
\text { Talent, Athlete }\end{array}$ & 6 & $31,5 \%$ \\
\hline
\end{tabular}




\begin{tabular}{|l|l|l|c|c|}
\hline 3. & Blending & & - & - \\
\hline 4. & Clipping & & - & - \\
\hline 5. & Acronym & SEA & 1 & $5,2 \%$ \\
\hline 6. & Abbreviation & PRSI, IOAC & 2 & $10,6 \%$ \\
\hline 7. & Compounding & Breaststroke, Championship & 2 & $10,6 \%$ \\
\hline 8. & Back Formation & - & - & - \\
\hline 9. & Inflection & $\begin{array}{l}\text { Swimming, Competing, Challenges, } \\
\text { Talents, Athletes, Training, Games, } \\
\text { Olympics }\end{array}$ & 8 & $42,1 \%$ \\
\hline \multicolumn{2}{|l|}{} & 19 & $100 \%$ \\
\hline
\end{tabular}

In the first article, it was found that $\operatorname{six}(6)$ or $31.5 \%$ data were classified as borrowing words, one (1) or $5.2 \%$ were acronyms, two (2) or $10.6 \%$ were abbreviations, two (2) or $10.2 \%$ were compounding, and eight (8) or $42.1 \%$ were categorized as inflections. So the most common type of word formation in this article is inflection words.

Tabel 2. Registers Found in the Second Sport Article of Jakarta Post Online Newspaper

\begin{tabular}{|c|c|c|c|c|}
\hline No & Word Formation & Registers & Frequency & Percentage \\
\hline 1. & Coinage & - & - & - \\
\hline 2. & Borrowing & $\begin{array}{l}\text { Trophy, Nation, National Stadium, } \\
\text { Player, Challenge, Tournament, } \\
\text { Captain, Defender, Final, Qualify, } \\
\text { Competition }\end{array}$ & $\begin{array}{l}1 \\
2\end{array}$ & $52,2 \%$ \\
\hline 3. & Blending & - & - & - \\
\hline 4. & Clipping & - & - & - \\
\hline 5. & Acronym & - & - & - \\
\hline 6. & Abbreviation & UEFA & 1 & $4,3 \%$ \\
\hline 7. & Compounding & Championship, Football & 2 & $8,7 \%$ \\
\hline 8. & Back Formation & - & - & - \\
\hline 9. & Inflection & $\begin{array}{l}\text { Supporters, Players, Finals, Matches, } \\
\text { Nations, Wins, Ranked, Sporting }\end{array}$ & 8 & $34,8 \%$ \\
\hline Total & & & $\begin{array}{l}2 \\
3\end{array}$ & $100 \%$ \\
\hline
\end{tabular}

In the second article, it was found that twelve (12) or 52,2\% data were classified as borrowing words, one (1) or $4,3 \%$ were abbreviations, two (2) or $8,7 \%$ were compounding, and eight (8) or $34,8 \%$ were categorized as inflections. So the most common type of word formation in this article is borrowing words.

Tabel. 3 Registers Found in the Third Sport Article of Jakarta Post Online Newspaper

\begin{tabular}{|c|l|c|c|c|}
\hline No & Word Formation & Registers & Frequency & Percentage \\
\hline 1. & Coinage & - & - & \\
\hline
\end{tabular}




\begin{tabular}{|c|c|c|c|c|}
\hline 2. & Borrowing & $\begin{array}{|lr|}\text { Congress, } & \text { Competition, } \\
\text { Confederation, } & \text { Organization, } \\
\text { National, Tournament, Group }\end{array}$ & 7 & $31,8 \%$ \\
\hline 3. & Blending & - & - & - \\
\hline 4. & Clipping & - & - & - \\
\hline 5. & Acronym & $\begin{array}{l}\text { FIFA, } \\
\text { CONCACAF, FIFPRO }\end{array}$ & 4 & $18,2 \%$ \\
\hline 6. & Abbreviation & UEFA, AFC & 2 & $9,1 \%$ \\
\hline 7. & Compounding & Football & 1 & $4,5 \%$ \\
\hline 8. & Back Formation & - & - & \\
\hline 9. & Inflection & $\begin{array}{lcc}\text { Groups, } & \text { Matches, } \quad \text { Sports, } \\
\text { Qualifiers, } & \text { Players, } & \text { Leagues, } \\
\text { Confederations, Organizes }\end{array}$ & 8 & $36,4 \%$ \\
\hline Tota & & & 22 & $100 \%$ \\
\hline
\end{tabular}

Moreover, in the third article, it was found that seven (7) or 31,8\% data were classified as borrowing words, four (4) or 18,2\% as acronyms, two (2) or 9,1\% were abbreviations, one (1) or $4,5 \%$ were compounding, and eight (8) or $36,4 \%$ were categorized as inflections. So the most common type of word formation in this article is inflection words.

\section{Discussion}

Referring to the findings of the research, it was found that the most word formation found on the sport register written The Jakarta Post online newspaper was borrowing words. It dealt with the second research question on what word formation form which is mostly appear in the sport news in online newspaper. Since borrowing word is one of the words formation process to create new words adapted from other language. It is formed from other languages. These words are borrowing from several languages, such as Latin, French, and Greek. The writer believes that the use of those borrowing words because most scientific languages about medical do come from other languages, such as Latin and Greek. As cited from The Etymology of Sporting Event Names (babbel.com) the origin of terms related to sports generally comes from Greek and Latin; and the adoption of German and French.

There were twenty five borrowing words in this research found and it mostly came from Latin such as stadium comes from the Greek "stadion", Olympic came from Greek "olympios", Captain came from the Old French word "capitaine", Tournament from Old French word "tornement", Athlete came from the Latin word "athleta", Nation is derived from the Old French "nacion", Defender derived from the Old French word "defendeor", Congress came from Latin "congressus", Qualify come from the French "Qualifier".

Then, the writer was able to come up with a compilation of sport articles registers as the output of her study based on the findings made. This compilation is called The Glossary of Sport Register. The glossary contains definitions for terms in the main text discussed that may be unfamiliar or unclear to the average readers. In this 
case, this glossary is presented alphabetically with its contextual definitions of sport registers. It is hoped that this product will give the contribution to help the common reader of sport news to get easier comprehension of sport article..

\section{CONCLUSION}

Based on the research findings, the researcher concludes that there are many registers to be found in sports news in the Jakarta Post online newspaper. Registers are found based on data from word formation. So, based on these data, the writer found the types of registers, namely borrowing words, acronyms, abbreviations, compounding and inflections. The register form is not only in the form of words but also phrases. The registers found are almost entirely in borrowing word formation, because most sports words are adapted from other languages such as Latin, Greek, and French, and from a list of words and phrases sports register can be made a Glossary. As we know that a glossary can be a mini dictionary that can provide an explanation of the meaning of words and phrases for readers. Reading the glossary can be a solution for ordinary people or readers to get information about things they don't understand.

Based on the conclusion above, the writer suggests that the result of this research finding might support the data for further research who are interested in investigating the registers based on word formation process. For further researcher, the writer suggests to conduct the same study with different data and giving information about registers in depth.

\section{REFERENCES}

Ambarsari, Nur Ratih \& Rusnaningtias, Erlita. (2016). The Study of Register Used by Doctors and Nurses at Adi Husada Undaan Wetan Hospital Surabaya. Anglicist Volume 05 No 01 (February 2016).

Apriyanto, S., \& Anum, A. (2018). Gender Dynamics on Speaking Interaction in the College Classroom. Jurnal Smart, 4(2), 73. https://doi.org/10.26638/js.692.203x

Ayu, I., Erlina, H., Santoso, D., \& Apriyanto, S. (2020). Perspective of Parents of Online Learning in Pandemic Covid-19. Journal of Research in Business, Economics, and Education, 2(6), 1346-1350.

Bauer, L. (1983). English Word Formation. Cambridge: Cambridge University Press. Biber.

Bowen, G. A. (2009). Document analysis as a qualitative research method. Qualitative Research Journal, 9(2), 27-40.

Budiarsa, M. (2015). Language, Dialect and Register in A Sociolinguistic Perspective. RETORIKA: Jurnal Ilmu Bahasa, Vol. 1, No. 2 Oktober 2015, 379-387.

Dalman, Hesti, \& Apriyanto, S. (2020). Conversational implicature: A pragmatic study of "our conversation" in learning at university. International Journal of Psychosocial Rehabilitation, 24(8), 4332-4340. https://doi.org/10.37200/IJPR/V24I8/PR280450 
Delahunty, G. P., \& Garvey, J. J. (2010). The English Language: From Sound to Sense. Colorado: WAC Clearinghouse.

Douglas \& Finegan, Edward. (1994). Sociolinguistic Perspectives on Register. Education Limited.

Faradisa, A. Aziz, A.Z. Yasin, B. (2019). An Analysis of Word Formation Processes Found in Instagram. Research in English and Education (READ), 4(2), 52-64, June 2019

Freeman, D. L. (1986). Technique and Principles In Language Teaching. New York: Oxford University Press.

Halliday, M. A. K. (1978). Language as social semiotic: The social interpretation of language and meaning. London: Edward Arnold

Holmes, J. (2001). An Introduction to Linguistic (Second Edition). UK: Pearson

Holmes, J. (2014). An Introduction to Sociolinguistics (Fourth Edition). London:Longman Group Limited

Holmes, J.(2013). An Introduction to Sociolinguistics. England: Pearson Educated Limited

Katamba, Francis. (1993). Morphology: Modern Linguistics Series. New Jersey: Prentice hall inc.

Kentika, Kasiyamo \& Tino .(2018). "Analysis of The Registers in Sports Articles in The Jakarta Globe Online Newspaper". Thesis. Education Faculty. Universitas Ahmad Dahlan. Magister of English Education. Yogyakarta.

Kusuma, H. A., \& Apriyanto, S. (2018). Strategy on Developing English Learning Material for Specific Purposes. IJECA (International Journal of Education and Curriculum Application), 1(3), 39. https://doi.org/10.31764/ijeca.v1i3.2144

Mega, Ismail. (2012). A Descriptive study of Register Used in Ticketing Division at Tanjung Emas Semarang. Unpublished Research Paper. Surakarta: UMS.

Moreno \& Skorczynska. (2013). Corpus Analysis and Register Variation: A Field in Need of an Update. 5th International Conference on Corpus Linguistics (CILC2013). Procedia- Social and Behavioral Sciences 95 (2013) 402-408. New York: Oxford University Press.

Mulyani R, Suryani L. (2019). Linguistics Varieties:Register in English Fanfiction Kpop "Miss Perfect Idol". PROJECT:Professional Journal of English Education. Volume 2, No. 5, September 2019 pp 665-674

Nafia, F. Rustono, Rustona. (2019). The Register Form of Pesantren Community in Semarang. Seloka: Jurnal Pendidikan Bahasa dan Sastra Indonesia. 8(1):28-38.

Pateda, Mansoer. (1987). Sosiolinguistik. Bandung: Angkasa.

Patel, M. F., \& Jain, P. M. (2008). English Language Teaching (Methods, Tools, and Technique). Jaipur: Sunrise.

Plag, I. (2003). Word-Formation in English. Cambridge:Cambridge University Press. Rosaria, Anik Isna (2008) A Descriptive Study of English Registers Used in Trading in "Bisnis Indonesia" Newspaper. Skripsi thesis, Universitas Muhammadiyah Surakarta. 
Siahaan, S. (2008). The English Paragraph. Yogyakarta: Graha Ilmu.

Subyantoro, S., \& Apriyanto, S. (2020). Impoliteness in Indonesian Language Hate

Speech on Social Media Contained in the Instagram Account. Journal of Advances in Linguistics, 11, 36-46. https://doi.org/10.24297/jal.v11i.8655

Sugiyono (2008). Metode Penelitian Kuantitatif, Kualitatif dan R\&D. Alfabeta.

Wardaugh, Ronald. (1998). An Introduction to Sociolinguistics. UK: Blackwell Publishers Ltd

www.thejakartapost.com Website of the Jakarta post

Yule, George. (2006). The Study of Language (3th Edition). Cambridge: Cambridge University Press 